\title{
UNRAVELING THE "SUBURBAN FERTILITY HYPOTHESIS": DEMOGRAPHIC IMPLICATIONS AND TERRITORIAL CONSEQUENCES
}

\author{
LUca SALVATI \\ Council for Agricultural Research and Economics, Arezzo, e-mail: luca.salvati@crea.gov.it \\ Ilaria ZAMBON \\ Department of Agricultural and Forestry Sciences, Tuscia University, Viterbo, \\ e-mail: ilaria.zambon@unitus.it
}

\begin{abstract}
A complex interplay among socioeconomic transformations and the underlying demographic trends has occurred along the long-term development of European countries. For instance, fertility plays a key role along the urban-rural gradient contributing to understand population patterns and processes and allowing identification of factors, drivers and consequences of demographic transitions. This contribution focuses on the relationship between urban growth and demographic transition, discussing whether discontinuous and dispersed urban expansion can be associated with a specific phase of demographic transition, especially a higher suburban fertility compared with urban and rural areas. A review of the 'suburban fertility hypothesis' based on earlier studies carried out in advanced economies, with a specific focus on Europe, indicates that urban sprawl is associated to younger and larger families whose childbearing behaviors determine positive feedbacks in terms of local fertility and demographic dynamics at large, with spatial heterogeneity across European regions and countries.
\end{abstract}

Keywords: fertility; demographic transition; suburban fertility; Europe.

Sažetak: Tokom dugoročnog razvoja evropskih zemalja došlo je do složene međuzavisnosti između socio-ekonomskih promena i osnovnih demografskih trendova. Na primer, plodnost ima ključnu ulogu u urbano-ruralnom gradijentu, doprinoseći razumevanju populacionih obrazaca i procesa tako što omogućava identifikaciju faktora, pokretača i posledica demografskih tranzicija. Ovaj rad se fokusira na odnos između urbanog rasta i demografske tranzicije, raspravljajući o tome može li se diskontinuirana i raspršena urbana ekspanzija povezati sa specifičnom fazom demografske tranzicije, naročito sa visokim vrednostima suburbanog fertiliteta u poređenju sa urbanim i ruralnim oblastima. Peispitivanje „hipoteze o suburbanoj (prigradskoj) plodnosti“ zasnovane na ranijim studijama koje su sprovedene $\mathrm{u}$ naprednim ekonomijama, sa posebnim fokusom na Evropu, ukazuje da je urbano širenje povezano sa mlađim i većim porodicama čija dečja reproduktivna ponašanja determinišu pozitivne efekte lokalnog fertiliteta i demografske dinamike uopšte, s prostornom heterogenošću širom evropskih regiona i zemalja.

Ključne reči: plodnost, demografska tranzicija, prigradska plodnost, Evropa. 


\section{INTRODUCTION}

A complex interchange among socioeconomic change and the underlying demographic trends has occurred along the long-term development of European countries, especially in recent decades (Kulu \& Boyle, 2009; Kulu et al., 2009; Van Criekingen, 2010; Lesthaeghe, 2010; Haase et al., 2010; Van Nimwegen, 2013; Salvati, 2018). Demographic transitions have occurred since the $18^{\text {th }}$ century, transforming high fertility and mortality rates characterized by young population toward decreasing demographic rates and ageing (Lee, 2003; Coleman, 2004; Harbison \& Robinson, 2002; Lee, 2003; Lee \& Reher, 2011; Lesthaeghe \& Neidert, 2006; Lesthaeghe, 2010; Blue \& Espenshade, 2011; Lesthaeghe \& Surkyn, 2004; Reher 2011; Sharlin, 1986; Surkyn \& Lesthaeghe, 2004). Decreasing birth and death rates from traditionally high levels characterized the so called 'first demographic transition' (Coleman, 2006). This transition was observed over a sufficiently long time interval ending with the highest urban concentration ever observed in advanced countries (Salvati, 2018). The 'second demographic transition' has happened together with social transformations and population redistribution at regional scale (Alperovich, 1983; van de Kaa, 2001), enlightening changes in individual and household characteristics, fertility, sexual and childbearing behaviors (Lesthaeghe \& Surkyn, 2004; Coleman, 2004, 2006; Harbison \& Robinson, 2002), triggering widespread aging and greater heterogeneity in population dynamics, time of childbearing, household's size, individual choices concerning marriage or cohabiting at the same time (Billari \& Kohler, 2004; Coleman, 2006; Haase et al., 2010; Kreyenfeld et al., 2012). Moreover, original territorial structures, more oriented toward polycentric development and spatially balanced settlements, have been progressively established in advanced economies, and more specifically in Europe, defining a new spatial configuration and relationships among cities and suburbs (Liu, 2005; Kulu et al., 2009; Lesthaeghe \& Neidert 2006; Caldwell \& Schindlmayr 2003; Coleman, 2006; 2008; Kalmijn \& van Tubergen, 2006; Sobotka \& Toulemon, 2008; Goldstein et al., 2009; Rontos 2007, 2010; Salvati, 2018).

Demographic dynamics result to be sensitive to economic cycles (Kertzer et al., 2009; Kreyenfeld et al., 2012; Lee, 2003; Reher, 2011; Rontos, 2010; Salvati, 2018; Goldstein et al., 2013), evidencing apparent (and more latent) relationships among socio-demographic factors and variability in economic performances (Reher, 2011). Demographic factors, e.g. the changing rates of marriage, cohabitation and separation (Kohler et al., 2002), have studied extensively during the second demographic transition (Kulu \& Boyle, 2009). For instance, changing gender roles emerged as women's socioeconomic characteristics (Surkyn \& Lesthaeghe, 2004; van de Kaa, 2001; Kulu \& 
Boyle, 2009; Vikat, 2004), including job market engagement (Andersson 2000; Engelhardt et al., 2004) and educational achievement (Hoem et al., 2006a, 2006b), defining new fertility purposes and behaviors (Kulu \& Boyle, 2009). With demographic transitions, life expectancy turned out to be longer with joint reductions in mortality and fertility, which can be detected following the spatial variation of population growth rates (Lee, 2003; Blue \& Espenshade, 2011; Howell et al., 2016; Salvati, 2018). Demographic transitions reflect socioeconomic change along urban-rural gradients (Walford \& Kurek, 2016; Boyle, 2003; Chorianopoulos et al., 2010; 2014; Salvati \& Sabbi 2014; Salvati, 2018). Based on these premises, the present paper focuses on the relationship between urban sprawl and demographic transitions, in order to investigate if different types of urban growth can be associated with specific demographic trends, especially fertility. Based on a literature review, our contribution specifically refers to the assumption that suburban fertility rose over time in comparison with both urban and rural fertility (the so called 'suburban fertility hypothesis').

\section{THE SPATIAL DIMENSION OF FERTILITY}

Assuming that fertility patterns and processes are linked with factors, drivers and consequences intimately associated with demographic transitions (Kulu \& Washbrook, 2014; Kurek et al., 2015; Kabisch et al., 2012; Boyle, 2003), fertility plays a pivotal role along urban-rural gradients. Sharlin (1986) summarized general trends of fertility in Europe along urban-rural gradients: (I) low urban marital fertility in rural contexts before the overall decline in fertility; (II) a declining marital fertility mainly in urban areas; (III) a fast decline in urban fertility followed by increasing rural-urban gap, and (IV) marital fertility in rural areas only slightly higher than in urban regions in the post-transition period (Kulu et al., 2007). Fertility differences across regions are intimately connected with the local context (Hank 2001, 2002; Caltabiano, 2008; Kertzer et al., 2009). Different desirable family sizes elucidate fertility differences among rural centers and urban areas (Kulu et al., 2011). Within urban areas, suburbs were found to record higher fertility (Kulu et al., 2009), with single-family households related with higher fertility (Kulu \& Vikat 2007). These differences were particularly intense when controlling for the socioeconomic configuration of each study area (Kulu \& Boyle, 2009), suggesting that contextual effects outline fertility choices. Spatial differences in urban and rural fertility rose over time (Sobotka, 2003; Sobotka et al., 2005; Kulu et al., 2009), whereas temporal differences in fertility was evident only recently. As an outcome, postponement has been more marked in larger regions rather than in smaller contexts (Kulu et al., 2007; Balbo et al., 2013). 
In addition to differences among urban and rural fertility during the demographic transition (Kulu et al., 2007), the reasons of fertility difference across the settlements reveal constraints on family size and work-related configurations (Sharlin, 1986). Besides, the costs of children fluctuated among urban and rural locations, as well as the impact of religious and social standards on individual behavior mixed with settlement size (Kulu \& Steele, 2013; Quillan, 2004). Another factor shaping urban-rural fertility variations is the educational composition, revealing spatial differences in childlessness (Hoem, 2005; Andersson et al., 2009; Kulu, 2011). Fertility variation by residence may also derive from the larger portion of students in urban areas than in small and rural contexts (Hank 2001; Kulu et al., 2007; Kulu, 2011). Population growth in suburban areas can be the consequence of increased in-migration (Kurek et al., 2015; van de Kaa, 2001; Sobotka, 2008; Lesthaeghe, 2010). Residential mobility may inspire couples to have more children (Vobecka \& Piguet, 2012). In this regard, suburban areas recorded higher fertility rates than urban centers and differences in fertility within different residential contexts consolidated when controlling for population composition and specific migration patterns (Kulu \& Washbrook, 2014; Kurek et al., 2015).

\section{SUBURBAN FERTILITY IN EUROPE}

Urban fertility, including both marital and overall, was lower than rural fertility during the last part of the first demographic transition, decreasing more rapidly with the second transition (Sharlin, 1986; Kulu \& Boyle, 2009). An increasing attention to spatial features of fertility levels emerged in recent literature (Hank 2001; Thygesen et al., 2005; De Beer \& Deerenberg, 2007; Kulu et al., 2007; 2009), since urban-rural fertility variations may have decreased over time, but significant differences among various types of settlement still persist nowadays (Kulu, Vikat, \& Andersson, 2007; Kulu, 2011). Fertility levels were higher in rural areas or small towns and lower in large cities, e.g. in the United States (Glusker et al., 2000), Eastern Europe (Burcin \& Kučera, 2000; Vobecká \& Piguet, 2012; Vojtěchovská, 2000; Kulu, 2005; 2006; Philipov \& Kohler, 2001), Northern Europe (Kulu et al., 2007; Thygesen, Knudsen \& Keiding, 2005), England and Wales (Boyle et al., 2007; Tromans, Natamba \& Jefferies, 2009), the Netherlands (De Beer \& Deerenberg, 2007; Mulder \& Wagner, 2001), Italy (Michielin, 2004; Vitali \& Billari, 2011), as well as, in Germany and Austria (Hank, 2001; Kulu, 2006). Suburban fertility in contemporary Europe has started to increase since the 1950s-1960s, following the post-war baby boom and growing suburbanization (Kulu et al., 2009). During the 1970s, a number of people in Europe moved to suburbs living in large apartments or semi-detached 
houses, thanks to the appropriateness of these areas for larger families with children (Kulu \& Vikat, 2007). Fertility rates became to be higher in such suburbs than in central cities (Kulu et al., 2007; 2009).

The residential background had an independent impact over fertility decision-making, where internal migration towards suburban areas in Europe revealed a higher fertility rate (Kulu, 2005; Andersson, 2004; Milewski, 2007; Kulu \& Boyle, 2009). Significant urban-rural differences in fertility behavior were influenced by individual socioeconomic characteristics (Kulu, 2011; Sharlin, 1986). Although studies on urbanrural fertility variation provided similar outlines - the larger the settlement, the lower the fertility levels - fertility rates are higher in smaller areas and lower in larger settlements (Kulu \& Washbrook, 2014). In these regards, compositional effects indicate that fertility rates differ among places since different people live in different settlements, while the contextual hypothesis assumes that factors connected to immediate living areas are of critical importance (Kulu \& Washbrook, 2014). For instance, couples with childbearing purposes may choose suburbs as more suitable residential contexts for families, while those with no childbirth plans may prefer larger settlements (Boyle et al., 2007; Kulu \& Washbrook, 2014). Both housing conditions and the larger suburban setting may concurrently account for high levels of suburban fertility (Kulu et al., 2009). Housing is a proxy for household-specific features affecting childbearing behavior, e.g. household economic resources or financial support from parents, while assuming also the role of a background variable reflecting the living situations and direct setting of a family, in some specific contexts (Kulu et al., 2009).

Several factors may contribute to higher suburban fertility (Kohler, 2000; Lutz \& Qiang, 2002; Kulu \& Vikat, 2007). Since demographic transitions have been accompanied by a long phase of urbanization, including both compact and dispersed expansion, young population living in low-density contexts in larger houses have a high expectation of having children (Zeitler \& Buys, 2015). This outcome emerged as a typical style of United States suburbs: suburban life has been considered as a part of the 'American dream', picturing younger and larger families. Nevertheless, today suburbs are aging (Lee et al., 2017). The most recent phase of urban growth would not be explicated by demographic variations typical of the second transition in some European countries, but the arrival of labor-related foreign immigrants has been of great importance. For instance, these international flows, mostly from central and eastern Europe and non-European developing countries, had been particularly strong in highly segregated labor markets e.g. in France, Spain and Italy (Domingo \& Gil-Alonso, 2007; Kohler \& Ortega, 2002). They were inclined to settle in core cities, predominantly in lowquality neighborhoods (Bayona et al., 2011; Bayona \& López-Gay, 2011), 
since central areas offer more work opportunities, better public transport, cheaper housing and easier networking among different immigrants (Champion, 2001; Buzar et al.; 2007; Bayona \& Gil-Alonso, 2012; Gil-Alonso et al., 2016).

\section{AN EMPIRICAL EXERCISE}

In the present study, a specific analysis was carried out at the urban and metropolitan level in Europe by exploiting official Eurostat statistics, with special regard with the demographic data disseminated by the Urban Audit program. This program developed by Eurostat aims at producing a socioeconomic profile of the main cities and metropolitan areas in Europe through the collection and dissemination of social, demographic and economic indicators on a more detailed geographical scale than the statistics usually disseminated by Eurostat. In particular, our study made use of demographic statistics for the last year available, building a demographic indicator - the crude birth rate, namely births per 1000 resident inhabitants - at local and regional scale in 671 urban agglomerations of 30 European countries. The urban scale has been identified through the spatial analysis' unit called 'inner city' in the Urban Audit program, encompassing the central municipality of the respective metropolitan area. The regional scale has been investigated considering 'Large Urban Zones' (LUZs), the spatial analysis' unit corresponding with the entire metropolitan area. To verify the suburban fertility hypothesis in European cities, an indicator was calculated by dividing the crude birth rate in suburban areas (LUZ) by the observed rate in strictly urban areas (inner cities). This indicator, calculated for each urban area, assumed a positive value when the birth rate was higher in suburban areas; a negative value indicated a higher birth rate in central cities compared with suburbs. Based on the available data published by Eurostat, the indicator refers to the last year available in each city of the sample, being representative of a time interval between 2015 and 2018. The indicator was subsequently analyzed by grouping cities by country and European region (Western, Northern, Central, Eastern and Southern). The percentage of cities showing a higher birth rate in the suburbs than in the central areas was calculated for each European country. Furthermore, classifying the cities studied in two groups (with higher fertility in the suburbs and with higher fertility in central areas), the average value of the indicator described above was calculated for each European country.

A significant spatial heterogeneity has been detected in the different European countries as regards the crude birth rate at urban and suburban scale (Table 1). In general, the percentage of cities where a higher birth rate was observed in suburbs than in central areas was relatively low in Western, 
Northern and Central Europe. In these contexts, which correspond to the most advanced economies in Europe, the highest birth rate was observed in central cities and the differences with suburbs were rather high (on average, about 10\% more in Germany, France, the United Kingdom, and more than $10 \%$ in Belgium and Denmark). The largest cities in these regions (Berlin, Paris, London) were in line with the overall trend. The percentage of cities where a higher birth rate was observed in the suburbs than in central areas increased in Eastern Europe, reaching the maximum values in Estonia and Slovenia and remaining particularly high also in Hungary, Poland and Romania. The difference in the birth rate between the suburbs and the central city was positive and ranged between $9 \%$ in the Slovak Republic and 3\% in Bulgaria and Czech Republic. Results for the main cities of this region were in line with the general trend. Finally, a particularly heterogeneous situation was observed in Southern Europe, where many cities had significantly higher values of suburban fertility than those observed in urban areas, and the main cities (e.g. Madrid and Barcelona in Spain, Rome and Naples in Italy, Athens in Greece) fully reflect this trend. Southern Europe is, in some way, a region that has recently experienced prolonged suburbanization, in transition towards urban models more similar with those observed in the most advanced European economies, with a slow recovery of fertility in central areas and a moderate decline in peripheral areas. At the same time, many cities in Southern Europe are still in a suburbanization phase characteristic of urban cycles typical of the most marginal areas, such as some Western and Northern European countries (Ireland and Norway) and most of the countries of Eastern Europe. The proposed approach can be considered a preliminary step of a more comprehensive analysis of urban and suburban fertility trends in the European continent using macro-scale demographic data at an appropriate spatio-temporal scale. Despite considered a gross indicator of fertility, urban and metropolitan (crude) birth rates may inform more refined demographic analysis considering specific indicators (e.g. total fertility rate) and providing an enriched analysis of local contexts, possibly influencing demographic gaps along urban-rural gradients.

\section{THE SPECIFICITY OF THE MEDITERRANEAN REGION}

The Second Demographic Transition has interested Southern Europe later than the others European countries with high rates of population loss, reaching the minimum values e.g. in Greece during the 1990s (Van Nimwegen, 2013). Effects of this transition on urban population gave rise to a slow shift from compact cities to more polycentric and spatially balanced areas (Rontos, 2010; Kabisch \& Haase, 2011; Salvati et al., 2015). Both internal and foreign migration influenced demographic changes 
Table 1. Spatial distribution of a demographic indicator assessing the regional gap in birth rates between suburban and urban areas in a sample of European cities, according to Eurostat Urban Audit statistics, 2015-2018.

\begin{tabular}{|c|c|c|c|c|c|c|}
\hline \multirow{2}{*}{ Country } & \multirow{2}{*}{$\begin{array}{c}\text { Total } \\
\text { number } \\
\text { of } \\
\text { cities }\end{array}$} & \multirow{2}{*}{$\begin{array}{c}\text { Higher } \\
\text { fertility } \\
\text { in } \\
\text { suburbs (\%) }\end{array}$} & \multicolumn{2}{|c|}{$\begin{array}{l}\text { Higher fertility in } \\
\text { central cities }\end{array}$} & \multicolumn{2}{|c|}{$\begin{array}{l}\text { Higher fertility in } \\
\text { Large Urban Zones }\end{array}$} \\
\hline & & & $\begin{array}{l}\text { Number } \\
\text { of cities }\end{array}$ & $\begin{array}{l}\text { Average } \\
\text { indicator }\end{array}$ & $\begin{array}{l}\text { Number of } \\
\text { cities }\end{array}$ & $\begin{array}{l}\text { Average } \\
\text { indicator }\end{array}$ \\
\hline \multicolumn{7}{|l|}{ Western Europe } \\
\hline Belgium & 11 & 18.2 & 9 & -11.5 & 2 & 3.4 \\
\hline France & 82 & 9.8 & 74 & -8.7 & 8 & 5.3 \\
\hline Ireland & 5 & 80.0 & 1 & -10.8 & 4 & 15.3 \\
\hline Luxembourg & 1 & 0.0 & 1 & -10.5 & & \\
\hline Netherlands & 36 & 19.4 & 29 & -5.3 & 7 & 1.1 \\
\hline United Kingdom & 47 & 23.4 & 36 & -10.6 & 11 & 3.4 \\
\hline \multicolumn{7}{|l|}{ Northern Europe } \\
\hline Denmark & 4 & 0.0 & 4 & -14.4 & & \\
\hline Finland & 7 & 28.6 & 5 & -3.7 & 2 & 2.2 \\
\hline Norway & 6 & 50.0 & 3 & -7.3 & 3 & 3.2 \\
\hline Sweden & 12 & 8.3 & 11 & -5.7 & 1 & 0.0 \\
\hline \multicolumn{7}{|l|}{ Central Europe } \\
\hline Austria & 6 & 33.3 & 4 & -6.7 & 2 & 8.4 \\
\hline Germany & 93 & 17.2 & 77 & -9.6 & 16 & 0.6 \\
\hline Switzerland & 10 & 10.0 & 9 & -9.6 & 1 & 0.3 \\
\hline \multicolumn{7}{|l|}{ Eastern Europe } \\
\hline Bulgaria & 17 & 35.3 & 11 & -4.4 & 6 & 3.5 \\
\hline Croatia & 7 & 57.1 & 3 & -3.6 & 4 & 3.4 \\
\hline Czech Republic & 15 & 33.3 & 10 & -2.2 & 5 & 2.6 \\
\hline Estonia & 2 & 100.0 & & & 2 & 6.7 \\
\hline Hungary & 19 & 84.2 & 3 & -3.8 & 16 & 8.5 \\
\hline Lithuania & 3 & 66.7 & 1 & -4.2 & 2 & 4.2 \\
\hline Latvia & 4 & 25.0 & 3 & -3.2 & 1 & 7.3 \\
\hline Poland & 58 & 87.9 & 7 & -1.5 & 51 & 5.4 \\
\hline Romania & 35 & 77.1 & 8 & -1.5 & 27 & 3.0 \\
\hline Slovenia & 2 & 100.0 & & & 2 & 6.1 \\
\hline Slovak Republic & 8 & 62.5 & 3 & -1.7 & 5 & 9.0 \\
\hline \multicolumn{7}{|l|}{ Southern Europe } \\
\hline Cyprus & 2 & 100.0 & & & 2 & 0.7 \\
\hline Greece & 9 & 22.2 & 7 & -10.1 & 2 & 14.0 \\
\hline Italy & 84 & 56.0 & 37 & -2.8 & 47 & 3.9 \\
\hline Malta & 1 & 100.0 & & & 1 & 10.5 \\
\hline Portugal & 12 & 41.7 & 7 & -7.7 & 5 & 1.7 \\
\hline Spain & 73 & 57.5 & 31 & -2.9 & 42 & 3.8 \\
\hline Total & 671 & 41.3 & 394 & -7.0 & 277 & 4.4 \\
\hline
\end{tabular}

Source: Own elaboration on Eurostat Urban Audit data (Inner Cities and Large Urban Zones). 
(Johnson et al., 2005; Van Criekingen, 2010; Blangiardo \& Rimoldi, 2013; van Bavel \& Reher, 2013; Taulbut \& Robinson, 2015). For instance, internal migration flows were focused on the main urban areas in Greece since the 1950s; contrarywise, a strong internal migration happened toward suburbs and rural contexts in the last decades, in corresponding with a stationary population growth in main cities, underlining new settlement models (Sayas, 2006; Kasimis, 2008; Morelli et al., 2014; Rontos et al., 2016; Salvati, 2018). Also in Spain many young families decided to move in suburbs. For instance, highly suburbanized areas e.g. in Madrid and Barcelona, recorded moderately high fertility; conversely smaller urban centres had lower fertility rates (Gil-Alonso et al., 2016; 2017; Pujadas et al., 2012; Pozo \& RodríguezMoya, 2003; Kohler \& Ortega, 2002). A marked fertility gap has been also detected in Northern Europe (Kulu \& Boyle, 2009; Kulu et al., 2007 \& 2009; Gil-Alonso et al., 2016; Kohler \& Ortega, 2002).

Sprawl has been extensively studied in Mediterranean metropolitan areas. For instance, urban expansion in Barcelona represented a sort of 'lock living' mode reflecting, in part, the characteristics of the United States suburban landscapes (Muñoz, 2003; Serra et al., 2014; Cuadrado-Ciuraneta et al., 2017). Peri-urban landscapes were therefore populated by single houses with private gardens and swimming pools (Garcia-López \& Muñiz, 2010; Saurí 2003), revealing the intrinsic relationship between luxury goods, income, socio-demographic characteristics and land resources (Vidal et al., 2011; Serra et al., 2014). However, the typical population segment fueling sprawl processes consists of large families, typically composed by a young couple with children, while one-component households (e.g. older people or adults who live alone) prefer to live in urban areas, because of increased accessibility to services (López-i-Villanueva et al., 2013). Following Tombolini et al. (2015), the spatial distribution of the elderly index reproduces the main demographic pattern at the base of urban sprawl. The elderly index was higher in central cities, as observed e.g. in Barcelona. In Rome, higher values of the elderly index were observed in rural municipalities and in some urban districts. In Athens, population preferred to live in certain areas depending on the age group (Zitti et al., 2017). Younger people (age class 18-44 years) were mainly concentrated in the areas that have undergone urban dispersion in recent times (Economidou, 1993; Zitti et al., 2017), resulting in a spatially heterogeneous population structure (Chorianopoulos et al., 2010). The oldest age class (> 64 years) was essentially located in the urban core of Greater Athens and in some coastal and inland peri-urban municipalities (Rontos \& Salvati, 2014; Zitti et al., 2017). 


\section{FUTURE CHALLENGES IN SPRAWLED AREAS}

As a result of economic and social changes, regional demographic regimes had changed in Europe (Hionidou, 1995; Leontidou, 1996; Salvati \& Carlucci, 2017). Heterogeneous demographic dynamics related with the second demographic transition have involved new family relationships, resulting in a declining fertility (Billari \& Kohler, 2004; Pinnelli \& Di Cesare, 2005; Haase et al., 2010; Kreyenfeld et al., 2012). These dynamics are having an influential effect both in urban centers and suburbs, redensifying but also diversifying these areas (Ogden \& Hall, 2000; Liu, 2005; Lee \& Painter, 2013; Salvati \& Carlucci, 2017). Recent recession shocks often lead to greater spatial complexity within the structural variations of urban and rural populations, reflecting the local scale consequences of the second demographic transition (Valkonen et al, 2000; Sobotka, Skirbekk, \& Philipov, 2011; Goldstein et al., 2013; Simou \& Koutsogeorgou, 2014). In fact, the recent recession has affected urban population dynamics, e.g. the metropolitan population (Dijkstra et al., 2015; Carbonaro et al., 2016; Salvati \& Carlucci, 2017). Recession-induced demographic decline and population ageing have enlarged urban vulnerability, affecting building cycles and shaping the housing and labor market as an outcome of improved class segregation and diverged distribution of economic activities (Pérez, 2010; Goldstein et al., 2013; Simou \& Koutsogeorgou, 2014; Ren, 2015; Salvati \& Carlucci, 2017).

The present contribution delineates the intimate relationship between urban sprawl and demographic transition (Carlucci et al., 2017; Kroll \& Kabisch, 2012). Recent literature indicated that mainly young population segments - with a greater propensity to childbearing - are involved in urban dispersion (Economidou, 1993; Zitti et al., 2017; Gil-Alonso et al., 2016, 2017; Pujadas et al., 2012; Pozo \& Rodríguez-Moya, 2003; Kohler \& Ortega, 2002; Salvati, 2018; Zeitler \& Buys, 2015) while elder people tend to live in major urban centers (Zeitler \& Buys, 2015; López-i-Villanueva et al., 2013; Rontos \& Salvati, 2014; Zitti et al., 2017). Literature also clarified connections between population structure and issues such as residential migration, social vulnerability, and demographic changes in urban and suburban areas (Marek \& Rantz, 2000; Andrew et al., 2008; 2012; Lucy \& Phillips, 2000; Lee et al., 2017). Local contexts with highly populated suburbs increasingly require strategies that indorse car-independent transport to (and from) all areas of the city, and to offer access to services and facilities that are reachable for nondrivers (Charlton et al., 2006; Lord et al., 2009; 2011; Zeitler et al., 2012). 
Economic changes have led to a change in housing preferences, especially in North America (Moos, 2016). In some Northern American metropolitan, young people are mostly concentrated in central areas or in high-density areas near public transportation connections expanding into the suburbs (Moos \& Mendez, 2015; Moos, 2014, 2016). These patterns reveal (i) preferences for an urban lifestyle, (ii) changing demography and household composition, (iii) increasing housing costs and (iv) changing economic prospects (Moore \& Skaburskis, 2004). Important spatial variability in European data supporting the suburban fertility hypothesis goes in the same direction, evidencing that suburban fertility in recent times was higher than urban fertility especially in Eastern and Southern Europe, as well as in more marginal contexts in other European regions. Such changes may be linked to lifestyles' evolution, since today many younger people prefer to live in smaller households than in the past. This choice changed also their fertility rate, e.g. having children later (Beaupre' et al., 2006; Moos, 2014, 2016). Furthermore, young adults prefer to live nearer to transit and urban amenities and to walk or cycle than to drive, demonstrating a growing urban lifestyle predilection (Moos, 2014). Focusing on the current labor market, young people experience higher 'risks' due to a growth of 'flexible work arrangements' (Beer et al., 2011; Furlong \& Cartmel, 2007), with lower income than in the past (Moos \& Mendez, 2015; Boudarbat et al., 2010; Moos, 2016). In contrast, baby boom generations and the current seniors are gradually found in suburban areas, growing in concentration in suburban neighborhoods in recent years (Patterson et al., 2014; Moos, 2016).

\section{CONCLUSIONS}

Literature review and the empirical evidence from statistical data suggest that, in recent years, the suburban fertility hypothesis has still valid in some urban contexts especially in marginal European regions. In contrast, in more advanced economies, this assumption seems to be less adequate in describing the more recent fertility trends on a local scale. A more accurate study adopting refined demographic indicators appears indispensable to provide a theoretical framework and a reliable empirical analysis on recent and future fertility trends along the urban-rural gradient in Europe. Implications of these transitions in the different European regions are particularly relevant for integrated management of urban areas. For instance, population structures increasingly dominated by older population segments in suburban districts may represent a problematic issue for urban planning in the coming decades. 


\section{REFERENCES}

Alperovich, G. (1983). An empirical study of population density gradients and their determinants. Journal of Regional Science, 23(4), 529-540.

Andersson G., Rønsen M., Knudsen L., Lappegård T., Neyer G., Skrede K., Teschner K. \& Vikat A. (2009). Cohort fertility patterns in the Nordic countries. Demographic Research, 20(14), 313-352.

Andersson, G. (2000). The impact of labor-force participation on childbearing behavior: Pro-cyclical fertility in Sweden during the 1980s and the 1990s. European Journal of Population, 16(4), 293-333.

Andersson, G. (2004). Childbearing after migration: Fertility patterns of foreign-born women in Sweden. International Migration Review, 8(2), 364-392.

Andrew, M. K., Mitnitski, A., Kirkland, S. A. \& Rockwood, K. (2012). The impact of social vulnerability on the survival of the fittest older adults. Age Ageing, 41, 161-165.

Andrew, M. K., Mitnitski, A. B. \& Rockwood, K. (2008). Social vulnerability, frailty and mortality in elderly people. PLoS ONE, 3, 1-8.

Balbo, N., Billari, F. C. \& Mills, M. (2013). Fertility in advanced societies: A review of research. European Journal of Population/Revue européenne de Démographie, 29(1), $1-38$.

Bayona, J. \& Gil-Alonso, F. (2012). Suburbanisation and international immigration: The case of the Barcelona Metropolitan Region (1998-2009). Tijdschrift voor Economische en Sociale Geografie, 103(3), 312-329.

Bayona, J. \& López-Gay, A. (2011). Concentración, segregación y movilidad residencial de los extranjeros en Barcelona. Documents d'Anàlisi Geogràfica, 57(3), 381-412.

Bayona, J., Gil-Alonso, F. \& Pujadas, I. (2011). Dinàmica residencial de la població estrangera en les principals' regions metropolitanes d'Espanya. Revista Catalana de Sociologia, 27, 15-32.

Beaupre, P., Turcotte, T. \& Milan, A. (2006). ”When is Junior Moving Out? Transitions from the Parental Home to Independence." (Research report in Canadian Social Trends No. 11-008). Ottawa: Statistics Canada, Ministry of Industry.

Beer, A., Clower, T. \& Faulkner, D. (2011). Consuming Housing? Transitions Through the Housing Market in the 21st Century. Portland, OR: The Policy Press.

Billari, F. \& Kohler H. P. (2004). Patterns of low and lowest-low fertility in Europe. Population Studies, 58(2), 161-176.

Blangiardo, G. C. \& Rimoldi, S. M. L. (2013). The potential demography: a tool for evaluating differences among countries in the European Union. Genus, 68 (3), 63-81.

Blue, L. \& Espenshade, T. J. (2011). Population momentum across the demographic transition. Population and Development Review, 37(4), 721-747.

Boudarbat, B., Lemieux, T. \& Riddell, C. (2010). The evolution of the returns to human capital in Canada, 1980-2005. Canadian Public Policy, 36(1), 63-89.

Boyle, P. J. (2003). Population geography: Does geography matter in fertility research? Progress in Human Geography, 27(5), 615-626. 
Boyle, P. J., Graham, E. \& Feng, Z. (2007). ”Contextualising demography: The significance of local clusters of fertility in Scotland." (MPIDR Working Paper WP-2007-036). Rostock: Max Planck Institute for Demographic Research.

Burcin, B. \& Kučera, T. (2000). Changes in Fertility and Mortality in The Czech Republic: An Attempt of Regional Demographic Analysis. In Kučera T., Kučerovă O., Opara O. \& Schaich E. (Eds), New Demographic Faces of Europe (pp. 371-417). Berlin:Springer.

Buzar, S., Ogden, P. E., Hall, R., Haase, A., Kabisch, S. \& Steinführer, A. (2007). Splintering urban populations: Emergent landscapes of reurbanisation in four European cities. Urban Studies, 44(4), 651-677.

Caldwell, J. C. \& Schindlmayr, T. (2003). Explanations of the fertility crisis in modern societies: a search for commonalities. Population Studies, 57 (3), 241-263.

Caltabiano, M. (2008). Has the fertility decline come to an end in the different regions of Italy? New insights from a cohort approach. Population, 63(1), 157-172.

Carbonaro, G., Leanza, E., McCann, P. \& Medda, F. (2018). Demographic decline, population aging, and modern financial approaches to urban policy. International Regional Science Review, 41(2), 210-232.

Carlucci, M., Grigoriadis, E., Rontos, K. \& Salvati, L. (2017). Revisiting a hegemonic concept: Long-term 'Mediterranean urbanization' in between city re-polarization and metropolitan decline. Applied Spatial Analysis and Policy, 10(3), 347-362.

Champion, A. G. (2001). A Changing Demographic Regime and Evolving Polycentric Urban Regions: Consequences for the Size, Composition and Distribution of City Populations. Urban Studies, 38(4), 657-677.

Charlton, J. L., Oxley, J., Fildes, B., Oxley, P., Newstead, S., Koppel, S. \& O'Hare, M. (2006). Characteristics of older drivers who adopt self-regulatory driving behaviours. Transportation Research Part F: Traffic Psychology and Behaviour, 9, 5.

Chorianopoulos I., Pagonis T., Koukoulas S. \& Drymoniti S. (2010). Planning, competitiveness and sprawl in the Mediterranean city: The case of Athens. Cities, 27(4), 249-259.

Chorianopoulos, I., Tsilimigkas G., Koukoulas, S. \& Balatsos T. (2014). The shift to competitiveness and a new phase of sprawl in the Mediterranean city: Enterprises guiding growth in Messoghia - Athens. Cities, 39, 133-143.

Coleman, D. (2004). Why we don't have to believe without doubting in the 'second demographic transition': Some agnostic comments. Vienna Yearbook of Population Research 2004. Vienna: Austrian Academy of Sciences, 11-24.

Coleman, D. (2006a). Europe's demographic future: Determinants, dimensions, and challenges. Population and Development Review, 32 (S1), 52-95.

Coleman, D. (2006b). Immigration and ethnic change in low-fertility countries: A third demographic transition. Population and development review, 32(3), 401-446.

Coleman, D. (2008). New Europe, new Diversity. Population Studies, 62 (1), 113-120.

Cuadrado-Ciuraneta, S., A. Durà-Guimerà \& Salvati L. (2017). Not Only Tourism: Unravelling Suburbanization, Second-home Expansion and 'Rural' Sprawl in Catalonia, Spain. Urban Geography, 38 (1), 66-89. 
De Beer, J. \& Deerenberg, I. (2007). An explanatory model for projecting regional fertility differences in the Netherlands. Population Research and Policy Review, 26, 511-528.

Dijkstra, L., Garcilazo, E. \& McCann, P. (2015). The effects of the global financial crisis on European regions and cities. Journal of Economic Geography, 15(5), 935-949.

Domingo, A. \& Gil-Alonso, F. (2007). Immigration and Changing Labour Force Structure in the Southern European Union. Population (English edition), 62(4), 709-727.

Economidou, E. (1993). The Attic landscape throughout the centuries and its human degradation. Landscape and Urban Planning, 24, 33-37.

Engelhardt, H., Ko"gel, T. \& Prskawetz, A. (2004). Fertility and women's employment reconsidered: A macro-level time series analysis for developed countries, 1960-2000. Population Studies, 58(1), 109-120.

Furlong, A \& Cartmel, F. (2007). Young People and Social Change: New Perspectives (2nd edition). Berkshire: McGraw-Hill.

Garcia-López, M. A. \& I. Muñiz. (2010). Employment Decentralisation: Polycentricity or Scatteration? The Case of Barcelona. Urban Studies, 47(14), 3035-3056.

Gil-Alonso, F., Bayona-i-Carrasco, J. \& Pujadas-i-Rúbies, I. (2016). From boom to crash: Spanish urban areas in a decade of change (2001-2011). European Urban and Regional Studies, 23(2), 198-216.

Gil-Alonso, F., Bayona-i-Carrasco, J., Villanueva, C. L. \& Pujadas, I. (2017). Diferencias geográficas de la fecundidad en España: una perspectiva provincial. Papeles de Geografía, 63, 21-38.

Glusker, A. I., Dobie, S. A., Madigan, D., Rosenblatt, R. A. \& Larson, E. H. (2000). Differences in fertility patterns between urban and rural women in Washington State 1983-1984 to 1993-1994. Women \& Health, 31(1), 55-70.

Goldstein, J. R., Sobotka T. \& Jasilioniene A. (2009). The end of "lowest-low" fertility? Population and Development Review, 35 (4), 663-699.

Goldstein, J., Kreyenfeld, M., Jasilioniene, A. \& Örsal, D. D. K. (2013). Fertility reactions to the "Great Recession" in Europe: Recent evidence from order specific data. Demographic Research, 29, 85-104.

Haase, A., Kabisch S., Steinführer A., Bouzarovski S., Hall R. \& Ogden P. (2010). Emergent spaces of reurbanisation: exploring the demographic dimension of inner-city residential change in a European setting, Population, Space and Place, 16 (5), 443-463.

Hank, K. (2001). Regional fertility differences in western Germany: An overview of the literature and recent descriptive findings. International Journal of Population Geography, 7(4), 243-257.

Hank, K. (2002). Regional social contexts and individual fertility decisions: A multilevel analysis of first and second births in western Germany. European Journal of Population, 18(3), 281-299.

Harbison, S. F. \& Robinson W. C. (2002). Policy implications of the next world demographic transition. Studies in Family Planning, 33(1), 37-48.

Hionidou, V. (1995). The demographic system of a Mediterranean Island: Mykonos, Greece 1859-1959. International Journal of Population Geography, 1(2), 125-146. 
Hoem, J. M. (2005). Why does Sweden have such high fertility? Demographic Research, 13(22), 559-572.

Hoem, J. M., Neyer, G. R. \& Andersson, G. (2006a). Education and childlessness: The relationship between educational field, educational level, and childlessness among Swedish women born in 1955-59. Demographic Research, 14(15), 331-380.

Hoem, J. M., Neyer, G. R. \& Andersson, G. (2006b). Education attainment and ultimate fertility among Swedish women born in 1955-59. Demographic Research, 14(16), 381-404.

Howell, F. M., Porter J. R. \& Matthews S. A. (Eds.) (2016). Recapturing Space: New MiddleRange Theory in Spatial Demography. Berlin: Springer.

Johnson, K. M., Voss P. R., Hammer R. B., Fuguitt G. V. \& Mcniven S. (2005). Temporal and spatial variation in age-specific net migration in the United States. Demography, 42(4), 791-812.,

Kabisch, N. \& Haase D. (2011). Diversifying European agglomerations: evidence of urban population trends for the 21st century. Population, Space and Place, 17 (3), 236-253.

Kabisch, N., Haase, D. \& Haase, A. (2012). Urban population development in Europe 19912008: The examples of Poland and UK. International Journal of Urban and Regional Research, 36(6), 1326-1348.

Kalmijn, M. \& Van Tubergen F. (2006). Ethnic intermarriage in the Netherlands, confirmations and refutations of accepted insights. European Journal of Population, 22 (4), 371-397.

Kasimis, C. (2008). Survival and expansion: migrants in Greek rural regions. Population, Space and Place, 14(6), 511-524.

Kertzer, D. I., White, M. J., Bernardi, L. \& Gabrielli, G. (2009). Italy's path to very low fertility: The adequacy of economic and second demographic transition theories. European Journal of Population, 25(1), 89-115.

Kohler, H. P. \& Ortega, J. A. (2002). Tempo-adjusted period parity progression measures: Assessing the implications of delayed childbearing for fertility in Sweden, the Netherlands and Spain. Demographic Research, 6(7), 91-144.

Kohler, H. P., Billari, F. C. \& Ortega, J. A. (2002). The emergence of lowest-low fertility in Europe during the 1990s. Population and Development Review, 28(4), 641-680.

Kreyenfeld, M., Andersson G. \& Pailhé, A. (2012). Economic Uncertainty and Family Dynamics in Europe: Introduction. Demographic Research, 27 (28), 835-852.

Kroll, F. \& Kabisch, N. (2012). The relation of diverging urban growth processes and demographic change along an urban-rural gradient. Population, Space and Place, 18(3), 260-276.

Kulu, H. (2005). Migration and fertility: Competing hypotheses re-examined. European Journal of Population, 21(1), 51-87.

Kulu, H. (2006). Fertility of internal migrants: Comparison between Austria and Poland. Population, Space and Place, 12(3), 147-170.

Kulu, H. (2013). Why do fertility levels vary between urban and rural areas? Regional Studies, 40(6), 895-912. 
Kulu, H. \& Boyle, P. J. (2009). High fertility in city suburbs: Compositional or contextual effects? European Journal of Population, 25(2), 157-174.

Kulu, H. \& Steele, F. (2013). Interrelationships between childbearing and housing transitions in the family life course. Demography, 50(5), 1687-1714.

Kulu, H. \& Vikat, A. (2007). Fertility differences by housing type: The effect of housing conditions or of selective moves? Demographic Research, 17(26), 775-802.

Kulu, H. \& Washbrook, E. (2014). Residential context, migration and fertility in a modern urban society. Advances in Life Course Research, 21, 168-182.

Kulu, H., Vikat, A. \& Andersson, G. (2007). Settlement size and fertility in the Nordic countries. Population Studies, 51(3), 265-285.

Kulu, H., Boyle, P. \& Andersson, G. (2009). High suburban fertility: Evidence from Four Northern European Countries. Demographic Research, 21(31), 915-944.

Kurek, S., Wójtowicz, M. \& Gałka, J. (2015). The changing role of migration and natural increase in suburban population growth: The case of a non-capital post-socialist city (The Krakow Metropolitan Area, Poland). Moravian Geographical Reports, 23(4), 59-70.

Lee, R. (2003). The demographic transition: three centuries of fundamental change. Journal of Economic Perspectives, 17 (4), 167-190.

Lee R. D. \& Reher D. S. (2011). Introduction: The landscape of demographic transition and its aftermath. Population and Development Review, 37 (s1), 1-7.

Lee, J., Hong, S. \& Park, Y. (2017). Predictable surprise: The spatial and social morphology of aging suburbs in the US metropolitan areas. Sustainability, 9(3), 458.

Lee, K. O. \& Painter, G. (2013). What happens to household formation in a recession? Journal of Urban Economics, 76, 93-109.

Lesthaeghe, R. J. \& Neidert L. (2006). The Second demographic transition in the United States: Exception or textbook example? Population and Development Review, 32 (4), 669-698.

Lesthaeghe, R. (2010). The Unfolding Story of the Second Demographic Transition. Population and Development Review, 36(2), 211-251.

Lesthaeghe, R. \& Surkyn J. (2004). "When History Moves On: The Foundations and Diffusion of a Second Demographic Transition." (Conference draft in Interface Demography). Brussels: Free University of Brussels.

Liu, L. (2005). Fertility trends in China's more developed urban districts: the case of four cities. Population, Space and Place 11 (5), 411-424.

López-i-Villanueva, C., Pujadas, R. I. \& Bayona Carrasco, J. (2013). Households within the residential mobility process: The case of the Barcelona metropolitan region. Arch. Stud. Urban. Reg., 28, 57-84.

Lord, S., Després, C. \& Ramadier, T. (2011). When mobility makes sense: A qualitative and longitudinal study of the daily mobility of the elderly. Journal of Environmental Psychology, 31, 1 .

Lord, S., Joerin, F. \& Thériault, M. (2009). Daily mobility of aging and elderly suburbanites: Trips, aspirations and meanings of mobility / La mobilité quotidienne de banlieusards vieillissants et âgés: Déplacements, aspirations et significations de la mobilité. The Canadian Geographer, 53, 3. 
Lucy, W. H. \& Phillips, D. L. (2000). Suburban decline: The next urban crisis. Issues Science and Technology, 17, 55-62.

Lutz, W. \& Qiang, R. (2002). Determinants of human population growth. Philosophical Transactions of the Royal Society B 357(1425), 1197-1210.

Marek, K. D. \& Rantz, M. J. (2000). Aging in Place: A New Model for Long-Term Care. Nursing Administration Quarterly, 24(3), 1-11.

Michielin, F. (2004). Lowest low fertility in an urban context: The role of migration in Turin, Italy. Population, Space and Place, 10(4), 331-347.

Milewski, N. (2007). First child of immigrant workers and their descendants in West Germany: Interrelation of events, disruption, or adaptation? Demographic Research, 17(29), 859-896.

Moore, E \& Skaburskis, A. (2004). Canada's increasing housing affordability burdens. Housing Studies, 19(3), 395-413.

Moos, M. (2014). 'Generationed' space: Societal restructuring and young adults' changing residential location patterns. The Canadian Geographer, 58(1), 11-33.

Moos, M. (2016). From gentrification to youthification? The increasing importance of young age in delineating high-density living. Urban Studies, 53(14), 2903-2920.

Moos, M. \& Mendez, P. (2015). Suburban ways of living and the geography of income: How homeownership, single-family dwellings and automobile use define the metropolitan social space. Urban Studies, 52(10), 1864-1882.

Morelli, V. G., Rontos K. \& Salvati L. (2014). Between suburbanisation and re-urbanisation: revisiting the urban life cycle in a Mediterranean compact city. Urban Research \& Practice, 7(1), 74-88.

Mulder, C. H. \& Wagner, M. (2001). The connection between family formation and firsttime home ownership in the context of West Germany and The Netherlands. European Journal of Population, 17(2), 137-164.

Muñoz, F. (2003). Lock Living: Urban Sprawl in Mediterranean Cities. Cities, 20(6), 381-385.

Ogden, P. E. \& Hall, R. (2000). Households, reurbanisation and the rise of living alone in the principal French cities 1975-1990. Urban Studies, 37(2), 367-390.

Patterson, Z., Saddier, S. \& Rezaei, A. (2014). Use of the urban core index to analyze residential mobility: The case of seniors in Canadian metropolitan regions. Journal of Transport Geography, 41, 116-125.

Pérez, J. M. G. (2010). The real estate and economic crisis: An opportunity for urban return and rehabilitation policies in Spain. Sustainability, 2(6), 1571-1601.

Philipov, D. \& Kohler, H. P. (2001). Tempo effects in the fertility decline in Eastern Europe: Evidence from Bulgaria, the Czech Republic, Hungary, Poland and Russia. European Journal of Population, 17(1), 37-60.

Pinnelli, A. \& Di Cesare, M. (2005). Human fertility: Sociodemographic aspects. Contraception, 72, 303-307.

Pozo, E. \& Rodríguez-Moya, J. M. (2003). Diferencias socioespaciales en la fecundidad madrileña en el cambio de siglo. Estudios Geográficos, LXIV (252), 455-486. 
Pujadas, I., Bayona, J., Gil-Alonso, F. \& López-Villanueva, C. (2012). Diferenciación espacial en los comportamientos demográficos: el caso de la fecundidad en la Región Metropolitana de Barcelona (1986-2010). In: Reques, P. \& De Cos, O. (Eds.), La población en clave territorial. Procesos, estructuras y perspectivas de análisis (pp. 145154). Santander: Universidad de Cantabria.

Quillan, K. (2004). When does religion influence fertility? Population and Development Review, 30(1), 25-56.

Reher, D. S. (2011). Economic and social implications of the Demographic transition. Population and Development Review, 37(s1), 11-33.

Ren, X. (2015). City power and urban fiscal crises: The USA, China, and India. International Journal of Urban Sciences, 19(1), 73-81.

Rontos, K. (2007). Prospects for a new family formation and for its impact on fertility: Some research evidences from Greece. Statistical Review, 3(1), 1-9.

Rontos, K. (2010). Demographic trends, young people's attitudes towards marriage and socio-economic changes related to family formation in Greece and in selected European Countries: A comparative analysis based on official and survey research data. International Journal of Criminology and Sociological Theory, 3(2), 543-562.

Rontos, K., Grigoriadis S., Sateriano A., Syrmali M., Vavouras I. \& Salvati L. (2016). Lost in Protest, Found in Segregation: Divided Cities in the Light of the 2015 'Oki' Referendum in Greece. City, Culture and Society, 7(3), 139-148.

Rontos, K. \& Salvati L. (2014). Is the Ratio of Present to Resident Population a Proxy for Urban Diffusion? A Case Study. International Journal of Ecological and Economic Statistics, 32(1), 75-82.

Salvati, L., Mavrakis A., Serra P. \& Carlucci M. (2015). Lost In translation, found in entropy: An exploratory data analysis of latent growth factors in a Mediterranean city (19602010). Applied Geography, 60, 107-119.

Salvati, L. \& Sabbi A. (2014). Identifying urban diffusion in compact cities through a comparative multivariate procedure. The Annals of Regional Science, 53(2), 557-575.

Salvati, L. \& Carlucci, M. (2017). Urban growth, population, and recession: Unveiling multiple spatial patterns of demographic indicators in a Mediterranean City. Population, Space and Place, 23(8), e2079.

Salvati, L. (2018). Population Structure and Economic Cycles in Greece: A Multidimensional Regional Analysis (1988-2016). Journal of Urban and Regional Analysis, X, 1, 61-78.

Saurí, D. (2003). Lights and Shadows of Urban Water Demand Management. The Case of the Metropolitan Region of Barcelona. European Planning Studies, 11(3), 229-243.

Sayas, J. P. (2006). Urban sprawl in the periurban coastal zones of Athens. The Greek Review of Social Research, 121(C), 71-104.,

Serra, P., Vera, A., Tulla, A. F. \& Salvati, L. (2014). Beyond urban-rural dichotomy: Exploring socioeconomic and land-use processes of change in Spain (1991-2011). Applied Geography, 55, 71-81.

Sharlin, A. (1986). Urban-rural differences in fertility in Europe during the demographic transition. In A. J. Coale \& S. C. Watkins (Eds.), The decline of fertility in Europe (pp. 234-260). Princeton: Princeton University Press. 
Simou, E. \& Koutsogeorgou, E. (2014). Effects of the economic crisis on health and healthcare in Greece in the literature from 2009 to 2013: A systematic review. Health Policy, 115, 111-119.

Sobotka, T. \& Toulemon L. (2008). Changing family and partnership behavior: common trends and persistent diversity across Europe. Demographic Research, 19(6), 85-138.

Sobotka, T. (2003). Tempo-quantum and period-cohort interplay in fertility changes in Europe. Demographic Research, 8(6), 152-214.

Sobotka, T., Winkler-Dworak, M., Testa, M. R., Lutz, W., Philipov, D., Engelhardt, H. \& Gisser, R. (2005). Monthly estimates of the quantum of fertility: Towards a fertility monitoring system in Austria. Vienna Yearbook of Population Research, 109-141.

Sobotka, T., Skirbekk, V. \& Philipov, D. (2011). Economic recession and fertility in the developed world. Population and Development Review, 37(2), 267-306.

Surkyn, J. \& Lesthaeghe, R. (2004). Value orientations and the second demographic transition (SDT) in Northern, Western and Southern Europe: An update. Demographic Research, Special Collection, S3(3), 45-86.

Taulbut, M. \& Robinson M. (2015). The chance to work in Britain: matching unemployed people to vacancies in good times and bad. Regional Studies, 49 (12), 2070-2086.

Thygesen, L. C., Knudsen, L. B. \& Keiding, N. (2005). Modelling regional variation of first-time births in Denmark 1980-1994 by an age-period-cohort model. Demographic Research, 13(23), 573-596.

Tombolini, I., Zambon, I., Ippolito, A., Grigoriadis, S., Serra, P. \& Salvati, L. (2015). Revisiting "Southern" sprawl: Urban growth, socio-spatial structure and the influence of local economic contexts. Economies, 3(4), 237-259.

Tromans, N., Natamba, E. \& Jefferies, J. (2009). Have women born outside the UK driven the rise in UK births since 2001? Population Trends, 136, 28- 42.

Valkonen, T., Martikainen, P., Jalovaara, M., Koskinen, S., Martelin, T. \& Mäkelä, P. (2000). Changes in socioeconomic inequalities in mortality during an economic boom and recession among middle aged men and women in Finland. The European Journal of Public Health, 10(4), 274-280.

Van Bavel, J. \& Reher D. S. (2013). The baby boom and its causes: What we knowand what we need to know. Population and Development Review, 39(2), 257-288.

Van Criekingen, M. (2010). 'Gentrifying the re-urbanisation debate', not vice versa: the uneven socio-spatial implications of changing transitions to adulthood in Brussels. Population, Space and Place, 16 (5), 381-394.

Van de Kaa, D. J. (2001). Postmodern fertility preferences: From changing value orientation to new behaviour. In R. A. Bulatao \& J. B. Casterline (Eds.), Global fertility transition: Supplement to Population and Development Review, Vol. 27 (pp. 290-331).

Van Nimwegen, N. (2013). Population change in Europe: turning challenges into opportunities. Genus, 69 (1), 103-125.

Vidal, M., Domene, E. \& Saurí, D. (2011). Changing Geographies of Water-related Consumption: Residential Swimming Pools in Suburban Barcelona. Area, 43(1), 67-75. 
Vikat, A. (2004). Women's labor force attachment and childbearing in Finland. Demographic Research, Special Collection, S3(8), 177-212.

Vitali, A. \& Billari, F. C. (2011). "A spatial panel analysis of Italian regional fertility." (Working Paper presented at the annual meeting of the PAA).

Vobecká, J. \& Piguet, V. (2012). Fertility, Natural Growth, and Migration in the Czech Republic: An Urban-Suburban-Rural Gradient Analysis of Long-Term Trends and Recent Reversals. Population, Space and Place, 18(3), 225-240.

Vojtěchovská, P. (2000). Population Development in Poland, In Kučera, T., Kučerova, O., Opara, O. \& Schaich, E. (Eds), New Demographic Faces of Europe (pp. 247-266). Berlin: Springer.

Zeitler, E. \& Buys, L. (2015). Mobility and out-of-home activities of older people living in suburban environments: 'Because I'm a driver, I don't have a problem'. Ageing \& Society, 35(4), 785-808.

Zeitler, E., Buys, L., Aird, R. \& Miller, E. (2012). Mobility and active ageing in suburban environments: Findings from in-depth interviews and person-based GPS tracking. Current Gerontology and Geriatrics Research, 2012(3), 1-10.

Zitti, M., Efstathios, G. \& Salvati, L. (2017). Beyond the 'Divided City': a manifesto for spatially balanced, sprawl-free post-crisis metropolises. Review of Applied SocioEconomic Research, 13(1), 95-109. 


\title{
PREISPITIVANJE "HIPOTEZE SUBURBANOG FERTILITETA": DEMOGRAFSKE IMPLIKACIJE I TERITORIJALNE POSLEDICE
}

\author{
Luca SALVATI, Ilaria ZAMBON
}

\begin{abstract}
REZIME
Regionalne rezlike u fertilitetu su usko povezane sa lokalnim kontekstom. Razlike u željenoj veličini porodice objašnjavaju razlike $u$ fertilitetu između ruralnih i urbanih područja. $U$ okviru urbanih celina, primetili smo da je u suburbanim (prigradskim) područjima viši nivo fertiliteta zabeležen u jednoporodičnim domaćinstvima. Ove razlike su posebno izražene u odnosu na socio-ekonomske pokazatelje posmatranih područja, uz primedbu da lokalni konteksti često determinišu nivo fertiliteta. Na osnovu uvida u brojna istraživanja koja su predstavljena u naučnoj literaturi pretpostavljamao da je u Evropi s vremenom došlo do porasta suburbanog fertiliteta u odnosu urbana i ruralna pordručja (tzv. 'hipoteza o prigradskoj plodnosti').

$\mathrm{Za}$ analizu prigradskog fertilitea korišćeni su zvanični podaci Eurostata za evropske gradove i metropole, na osnovu kojih su izvedene opšte stope nataliteta na lokalnom i regionalnom nivou u 671 urbanoj aglomeraciji iz 30 evropskih zemalja. Skaliranje urbanih područja je izvedeno pomoću jedinice za prostornu analizu koja se u Urban Audit programu naziva "unutrašnji grad", a koji obuhvata centralnu opštinu odgovarajućeg područja metropole. Regionalna skala je analizirana prema "velikim gradskim zonama" (Large Urban ZonesLUZ). Indikator je izračunat deljenjem opšte stope nataliteta u suburbanim područjima sa odgovarajućim stopama u strogo urbanim područjima (unutrašnjim-centralnim gradovima). Ovaj indikator ima pozitivnu vrednost kada je opšta stopa nataliteta viša u prigradskim, odnosno negativna kada je stopa viša u urbanim područjima.

Udeo gradova u kojima su opšte stope nataliteta više u suburbanim područjima nego u "unurtašnjim gradovima" je relatino nizak u Zapadnoj, Severnoj i Centralnoj Evropi. U tom smislu, najviše opšte stope nataliteta su zabeležene u unutrašnjim gradovima, a razlike u odnosu na predgrađa su prilično velike (u proseku oko 10\% u Nemačkoj, Francuskoj i Velikoj Britaniji, a više od 10\% u Belgiji i Danskoj). Udeo gradova u kojima je viši natalitet primećen u predgrađima nego u centralnim oblastima povećan je u Istočnoj Evropi, dostižući maksimalne vrednosti u Estoniji i Sloveniji, a na posebno visokom nivou je u Mađarskoj, Poljskoj i Rumuniji. Razlika u natalitetu između predgrađa i centralnih grada bila je pozitivna i kretala se između 9\% u Slovačkoj, i 3\% u Bugarskoj i Češkoj. Posebna heterogenost primećena je u Južnoj Evropi, gde su mnogi gradovi imali značajno više vrednosti nataliteta u prigradskim područjima.

Južna Evropa je, na neki način, region sa recentnom produženom suburbanizacijom, u tranziciji ka urbanim modelima sličnim onima u najnaprednijim evropskim ekonomijama, sa sporim oporavkom plodnosti u centralnim gradovima i umerenim padom u suburbanim područjima. Istovremeno, mnogi gradovi u Južnoj Evropi još uvek su u fazi suburbanizacije koja je karakteristična za urbane cikluse u najmarginalnijim područja, poput nekih u zemaljama Zapadne i Severne Evrope (Irska i Norveška), i većine zemalja Istočne Evrope.
\end{abstract}

Ključne reči: plodnost, demografska tranzicija, prigradska plodnost, Evropa. 